\title{
Fungi from Asian Karst formations III. Molecular and morphological characterization reveal new taxa in Phaeosphaeriaceae
}

\author{
Zhang $\mathrm{JF}^{1,2,3}$, Liu JK ${ }^{2,4}$, Jeewon $\mathrm{R}^{5}$, Wanasinghe $\mathrm{DN}^{6,7}$ and Liu $\mathrm{ZY}^{2^{*}}$ \\ ${ }^{1}$ Guizhou Tea Research Institute, Guizhou Academy of Agricultural Sciences, Guiyang 550006, Guizhou, P.R. China \\ ${ }^{2}$ Guizhou Key Laboratory of Agriculture Biotechnology, Guizhou Academy of Agricultural Sciences, Guiyang 550006, \\ Guizhou, P.R. China \\ ${ }^{3}$ Center of Excellence in Fungal Research and School of Sciences, Mae Fah Luang University, Chiang Rai 57100, \\ Thailand \\ ${ }^{4}$ Center for Bioinformatics, School of Life Science and Technology, University of Electronic Science and Technology of \\ China, Chengdu 611731, P.R. China \\ ${ }^{5}$ Department of Heath Sciences, Faculty of Science, University of Mauritius, Reduit 80837, Mauritius \\ ${ }^{6}$ Key Laboratory for Plant Diversity and Biogeography of East Asia, Kunming Institute of Botany, Chinese Academy of \\ Sciences, Kunming 650201, Yunnan, P.R. China \\ ${ }^{7}$ World Agroforestry Centre, East and Central Asia, Kunming 650201, Yunnan, P.R. China
}

Zhang JF, Liu JK, Jeewon R, Wanasinghe DN, Liu ZY 2019 - Fungi from Asian Karst formations III. Molecular and morphological characterization reveal new taxa in Phaeosphaeriaceae. Mycosphere 10(1), 202-220, Doi 10.5943/mycosphere/10/1/3

\begin{abstract}
An ongoing study on ascomycetes from Karst landforms in Guizhou Province, China yielded 6 new taxa that belong to the Phaeosphaeriaceae. These include 2 novel monotypic genera: Hydeopsis (with H. verrucispora sp. nov.) and Pseudoophiosphaerella (with P. huishuiensis sp. nov.), and two new species: Hydeomyces pinicola and Leptospora hydei. Multi-gene phylogenetic analyses of a concatenated LSU-ITS-SSU-TEF1- $\alpha$ sequence data were performed to infer their phylogenetic relationships. Hydeopsis is morphologically characterized by subglobose, papillate, dark brown to black ascomata, cellular pseudoparaphyses, clavate, bitunicate, fissitunicate asci and ellipsoidal to fusiform, hyaline to pale pigmented, 3-septate ascospores with a mucilaginous sheath. Hydeopsis is phylogenetically related to Dactylidina and Phaeopoacea, but can be recognized as a distinct lineage and these genera can also be distinguished based on morphology. Pseudoophiosphaerella is morphologically similar to Ophiosphaerella in having cylindric-clavate asci and scolecospores, but is phylogenetically distant from the latter and more closely related to Dlhawksworthia. Comprehensive illustrations and detailed descriptions of these taxa are provided, and relationships with allied genera or species are discussed based on comparative morphology and phylogenetic evidence.
\end{abstract}

Key words - 6 new taxa - Dothideomycetes - Multi-gene - Sexual morph - Phylogeny Taxonomy

\section{Introduction}

Pleosporales is the largest order of the Dothideomycetes and comprise around 80 families with a quarter of all described dothideomycetous fungi (Kodsueb et al. 2006, Kirk 2008, Zhang et al. 2008, 2012, Hyde et al. 2013, Tanaka et al. 2015, Jaklitsch \& Voglmayr 2016, Dai et al. 2017, 
Phookamsak et al. 2017, Liu et al. 2017, Ariyawansa et al. 2018, Wijayawardene et al. 2018). Most members of this order have been reported as playing important roles, and they can also change their lifestyles depending on environmental conditions/nature of substrates, and degrade dead plant materials or cause serious diseases in crops (Wong \& Hyde 2001, Promputtha et al. 2007, 2010, Ghimire \& Hyde 2008, Szilagyi-Zecchin et al. 2016, Yang et al. 2016). Following extensive collections, a number of novel taxa have been described from this order (Jayasiri et al. 2016, Wanasinghe et al. 2017, 2018). Phaeosphaeriaceae, one of the most species-rich families in Pleosporales, was initially introduced to accommodate 15 genera by Barr (1979) with Phaeosphaeria as type genus and P. oryzae as the type species. As of now, Phaeosphaeriaceae comprises 55 genera, with a number of novel species introduced recently (Huang et al. 2017, Senanayake et al. 2018, Yang et al. 2019).

Members of Phaeosphaeriaceae are distributed worldwide, and normally characterized by having small to medium-sized, depressed global or conical ascomata, bitunicate asci, hyaline or pigmented ascospores with or without septation, and coelomycetous asexual morphs (Zhang et al. 2012, Hyde et al. 2013, Phookamsak et al. 2014). Many species of this group are known as important plant pathogens, saprobes, endophytes and lichenicolous (Wang et al. 2007, Lawrey et al. 2012, Zhang et al. 2012, Hyde et al. 2013, Quaedvlieg et al. 2013). A recent study reported establishment of a new genus, Tintelnotia which can even cause cornea and nail infections in humans (Ahmed et al. 2017).

Fungi from karst landforms in the province of Guizhou in China have been documented in recent studies (Ariyawansa et al. 2016 a, b, c, Chen et al. 2017, Zhang et al. 2017a, b, 2018). As part of our ongoing studies on ascomycetous fungi from this region, four new isolates were obtained and identified as members of Phaeosphaeriaceae. Based on morphological characteristics and in-depth phylogenetic analyses of a combined LSU-ITS-SSU-TEF1- $\alpha$ sequence dataset, two novel monotypic genera Hydeopsis and Pseudoophiosphaerella, with 4 new species viz. Hydeomyces pinicola, Hydeopsis verrucispora, Leptospora hydei and Pseudoophiosphaerella huishuiensis are introduced in this study. The aim of this study is to describe these new taxa with detailed descriptions and illustrations, and also investigate their phylogenetic relationships within Phaeosphaeriaceae based on DNA sequence data derived from multi-genes.

\section{Materials \& Methods}

\section{Collection, examination and isolation of specimens}

Dead woody or herbaceous plant materials were collected from Guizhou Province of China from 2016 to 2017. The samples were taken back to laboratory and examined using a stereomicroscope (Motic SMZ 168), and the macro-morphological characters were captured by a stereomicroscope (Nikon SMZ800N) with a Cannon EOS 70D digital camera. Hand sections of fruiting bodies were made by a razor blade and mounted in a water drop for microscope studies and photomicrography. Micro-morphological characters were observed by differential interference contrast (DIC) using a Nikon ECLIPSE 80i compound microscope and captured by the Cannon EOS 600D digital camera. Measurements were processed in a Tarosoft $(\mathrm{R})$ Image Frame Work version 0.9.7 program, and photographic plates were edited in Adobe Photoshop CS6 (Adobe Systems Inc., USA).

The fungi were isolated using single spore isolation as described in Chomnunti et al. (2014). The single germinated ascospore was picked up and transferred to potato dextrose agar (PDA; 39 $\mathrm{g} / \mathrm{l}$ distilled water, Difco potato dextrose) for recording growth rates and culture characteristics (Liu et al. 2010). The specimens are deposited at the herbarium of Mae Fah Luang University (MFLU), Chiang Rai, Thailand, and Guizhou Academy of Agricultural Sciences (GZAAS), Guizhou, China. Living cultures are deposited at Mae Fah Luang University Culture Collection (MFLUCC) Chiang Rai, Thailand, and Guizhou Culture Collection (GZCC), Guizhou, China. Index Fungorum and Facesoffungi numbers are provided as stated in Jayasiri et al. (2015) and Index Fungorum (2019). New species are established as outlined by Jeewon \& Hyde (2016). 


\section{DNA extraction, PCR amplification and sequencing}

Total genomic DNA was extracted from fresh fungal mycelium with Ezup Column Fungi Genomic DNA Purification Kit (Sangon Biotech, Shanghai, P. R. China) following the manufacturer's protocol. DNA amplifications were performed by Polymerase Chain Reaction (PCR) in a $50 \mu \mathrm{l}$ reaction volume, which contained $19 \mu \mathrm{l}$ Distilled-Deionized-water, $25 \mu \mathrm{l}$ of $2 \times$ Power Taq PCR Master Mix (TIANGEN Co., China), $2 \mu \mathrm{l}$ of DNA template and $2 \mu \mathrm{l}$ of each forward and reverse primers. Four partial gene portions were used in this study. The primers of ITS4 and ITS5, NS1 and NS4 (White et al. 1990), LR0R and LR5 (Vilgalys \& Hester 1990), were used for amplifying the internal transcribed spacers (ITS), small subunit of the nuclear ribosomal RNA genes (SSU) and large subunit of the nuclear ribosomal RNA genes (LSU) respectively. The translation elongation factor 1-alpha region (TEF1- $\alpha$ ) was amplified by the primers of EF1-983F and EF1-2218R (Rehner 2001). The PCR thermal cycle programs for these four genes are as follows: $94{ }^{\circ} \mathrm{C}$ for $3 \mathrm{~min}$, followed by 40 cycles of denaturation at $94{ }^{\circ} \mathrm{C}$ for $45 \mathrm{~s}$, annealing at 56 ${ }^{\circ} \mathrm{C}$ for $50 \mathrm{~s}$, elongation at $72{ }^{\circ} \mathrm{C}$ for $1 \mathrm{~min}$, and a final extension at $72{ }^{\circ} \mathrm{C}$ for $10 \mathrm{~min}$. Quality of PCR products was checked by $1.2 \%$ agarose gel electrophoresis stained with ethidium bromide and then sent to Sangon Biotechnology Co., Ltd (Shanghai, P. R. China) for sequencing.

\section{Phylogenetic analyses}

Newly generated sequence data were initially subjected to blast search in NCBI. Appropriate sequences used for phylogenetic analyses were selected and downloaded from GenBank based on blast results and recent literature (Phookamsak et al. 2014, 2017, Liu et al. 2015, Abd-Elsalam et al. 2016, Ahmed et al. 2017, Tennakoon et al. 2016, Tibpromma et al. 2016, Hyde et al. 2017, Bakhshi et al. 2018, Maharachchikumbura et al. 2019, Yang et al. 2019). Each gene region was aligned with the MAFFT v. 7 online interface using default settings (http://mafft.cbrc.jp/alignment/server/), then improved manually and combined in the program BioEdit v. 7.2 (Hall 1999).

Phylogenies of the aligned sequence dataset were inferred from maximum likelihood (ML) and Bayesian Inference (BI) analyses. The ML analyses including 1000 bootstrap replicates were performed in the program of RAxMLGUI v. 1.5b1 (Silvestro \& Michalak 2012), and the best scoring tree was selected among suboptimal trees from each replicate by comparing likelihood scores under the GTR+GAMMA substitution model. Bayesian analyses were carried out by using MrBayes v. 3.2 (Ronquist et al. 2012), and the suitable models of evolution were estimated in MrModeltest 2.3 for each gene (Nylander 2008). Posterior probabilities (PP) (Rannala \& Yang 1996, Zhaxybayeva \& Gogarten 2002) were determined by Markov Chain Monte Carlo sampling (MCMC) in MrBayes v. 3.2. Six simultaneous Markov chains were run for 10000000 generations and trees were sampled every 100th generation. The temperature values were lowered to 0.15 , burn-in was set to 0.25 , and the run was automatically stopped as soon as the average standard deviation of split frequencies reached below 0.01. Trees were visualized with TreeView (Page 1996), and the layouts were done in the program of Adobe Illustrator CS v. 5 (Adobe Systems Inc., USA).

Table 1 Isolates used in the phylogenetic analyses. Newly generated sequences are in red.

\begin{tabular}{llllll}
\hline Taxon & Strain/Specimen No. & \multicolumn{2}{l}{ GenBank accession numbers } \\
\cline { 3 - 6 } & & LSU & ITS & SSU & TEF1- $\alpha$ \\
\hline Acericola italica & MFLUCC 13-0609 & MF167429 & MF167428 & MF167430 & --- \\
Allophaeosphaeria muriformia & MFLUCC 13-0349 & KP765681 & KP765680 & KP765682 & --- \\
Allophaeosphaeria subcylindrospora & MFLUCC 13-0380 & KT314183 & KT314184 & KT314185 & --- \\
Amarenographium ammophilae & MFLUCC 16-0296 & KU848197 & KU848196 & KU848198 & MG520894 \\
Amarenomyces dactylidis & MFLUCC 14-0207 & KY775575 & KY775577 & --- & --- \\
Ampelomyces quisqualis & CBS 129.79 & EU754128 & HQ108038 & EU754029 & --- \\
Bhatiellae rosae & MFLUCC 17-0664 & MG828989 & MG828873 & MG829101 & --- \\
Camarosporioides phragmitis & MFLUCC 13-0365 & KX572345 & KX572340 & KX572350 & KX572354 \\
Chaetosphaeronema achilleae & MFLUCC 16-0476 & KX765266 & KX765265 & --- & -- \\
\hline
\end{tabular}


Table 1 Continued.

\begin{tabular}{|c|c|c|c|c|c|}
\hline \multirow[t]{2}{*}{ Taxon } & \multirow[t]{2}{*}{ Strain/Specimen No. } & \multicolumn{4}{|c|}{ GenBank accession numbers } \\
\hline & & LSU & ITS & SSU & TEF1- $\alpha$ \\
\hline Chaetosphaeronema hispidulum & CBS 216.75 & KF251652 & KF251148 & EU754045 & --- \\
\hline Dactylidina dactylidis & MFLUCC 13-0618 & KP744473 & KP744432 & KP753946 & --- \\
\hline Dactylidina dactylidis & MFLUCC 14-0966 & MG829002 & MG828886 & MG829113 & MG829199 \\
\hline Dematiopleospora donetzica & MFLU 15-2199 & MG829005 & --- & MG829116 & --- \\
\hline Dematiopleospora mariae & MFLUCC 13-0612 & KJ749653 & KJ749654 & KJ749652 & KJ749655 \\
\hline Diederichomyces ficuzzae & CBS 128019 & JQ238616 & KP170647 & --- & --- \\
\hline Diederichomyces xanthomendozae & CBS 129666 & JQ238634 & KP170651 & --- & --- \\
\hline Dlhawksworthia clematidicola & MFLUCC 14-0910 & MG829011 & MG828901 & MG829120 & MG829202 \\
\hline Dlhawksworthia lonicerae & MFLUCC 14-0955 & MG829012 & MG828902 & MG829121 & MG829203 \\
\hline Embarria clematidis & MFLUCC 14-0652 & КT306593 & КT306949 & КT306956 & --- \\
\hline Embarria clematidis & MFLUCC 14-0976 & MG828987 & MG828871 & MG829099 & MG829194 \\
\hline Equiseticola fusispora & MFLUCC 14-0522 & KU987669 & KU987668 & KU987670 & MG520895 \\
\hline Galliicola pseudophaeosphaeria & MFLUCC 14-0524 & KT326693 & KT326692 & --- & MG520896 \\
\hline Hydeomyces desertipleosporoides & SQUCC 15259 & MK290839 & MK290841 & MK290843 & MK290848 \\
\hline Hydeomyces desertipleosporoides & SQUCC 15260 & MK290840 & MK290842 & MK290844 & MK290849 \\
\hline Hydeomyces pinicola & GZCC 19-0003 & MK522496 & MK522506 & MK522502 & MK523386 \\
\hline Hydeopsis verrucispora & MFLUCC 19-0163 & MK522498 & MK522508 & MK522504 & MK523388 \\
\hline Italica achilleae & MFLUCC 14-0959 & MG829013 & MG828903 & MG829122 & MG829204 \\
\hline Juncaceicola italica & MFLUCC 13-0750 & KX500107 & KX500110 & KX500108 & MG520897 \\
\hline Juncaceicola luzulae & MFLUCC 16-0780 & KX449530 & KX449529 & KX449531 & MG520898 \\
\hline Juncaceicola typharum & CBS 296.54 & KF251695 & KF251192 & --- & GU456287 \\
\hline Leptosphaeria doliolum & CBS 505.75 & GU301827 & JF740205 & GU296159 & GU349069 \\
\hline Leptospora galii & KUMCC 15-0521 & KX599548 & KX599547 & KX599549 & MG520899 \\
\hline Leptospora rubella & СРC 11006 & DQ195792 & DQ195780 & DQ195803 & --- \\
\hline Leptospora rubella & MFLU 16-0965 & KX757834 & KX757835 & --- & --- \\
\hline Leptospora thailandica & MFLUCC 16-0385 & KX655549 & KX655559 & KX655554 & KX655564 \\
\hline Leptospora hydei & GZCC 19-0004 & MK522497 & MK522507 & MK522503 & MK523387 \\
\hline Loratospora luzulae & MFLUCC 14-0826 & KT328495 & KT328497 & KT328496 & --- \\
\hline Melnikia anthoxanthii & MFLUCC 14-1010 & KU848204 & --- & KU848205 & --- \\
\hline Muriphaeosphaeria galatellae & MFLUCC 14-0614 & KT438329 & KT438333 & KT438331 & MG520900 \\
\hline Muriphaeosphaeria galatellae & MFLUCC 15-0769 & KT438330 & --- & KT438332 & --- \\
\hline Neosetophoma garethjonesii & MFLUCC 14-0528 & KY496738 & KY496758 & KY501126 & KY514402 \\
\hline Neosetophoma rosigena & MFLUCC 17-0768 & MG829037 & MG828928 & MG829143 & --- \\
\hline Neostagonospora arrhenather & MFLUCC 15-0464 & KX910091 & KX926417 & KX950402 & MG520901 \\
\hline Neostagonospora caricis & CBS 135092 & KF251667 & KF251163 & --- & --- \\
\hline Neostagonospora phragmitis & MFLUCC 16-0493 & KX910090 & KX926416 & KX950401 & MG520902 \\
\hline Neostagonosporella sichuanensis & MFLU 18-1223 & MH394690 & MK296469 & MH394687 & MK313854 \\
\hline Neostagonosporella sichuanensis & MFLUCC 18-1228 & MH368073 & MH368088 & MH368079 & MK313851 \\
\hline Neosulcatispora agaves & СРC 26407 & KT950867 & KT950853 & --- & --- \\
\hline Neosulcatispora strelitziae & СРC 25657 & KX228305 & KX228253 & --- & --- \\
\hline Nodulosphaeria guttulatum & MFLUCC 15-0069 & KY496726 & KY496746 & KY501115 & KY514394 \\
\hline Nodulosphaeria multiseptata & MFLUCC 15-0078 & KY496728 & KY496748 & KY501116 & KY514396 \\
\hline Nodulosphaeria scabiosae & MFLUCC 14-1111 & KU708846 & KU708850 & KU708842 & KU708854 \\
\hline Ophiobolopsis italica & MFLUCC 17-1791 & MG520959 & MG520939 & MG520977 & MG520903 \\
\hline Ophiobolus artemisiae & MFLUCC 14-1156 & KT315509 & KT315508 & MG520979 & MG520905 \\
\hline Ophiobolus disseminans & MFLUCC 17-1787 & MG520961 & MG520941 & MG520980 & MG520906 \\
\hline Ophiobolus ponticus & MFLUCC 17-2273 & MG520963 & MG520943 & MG520982 & MG520908 \\
\hline Ophiosimulans tanaceti & MFLUCC 14-0525 & KU738891 & KU738890 & KU738892 & MG520910 \\
\hline Ophiosphaerella agrostidis & MFLUCC 11-0152 & KM434281 & KM434271 & KM434290 & KM434299 \\
\hline Ophiosphaerella aquaticus & MFLUCC 14-0033 & KX767089 & KX767088 & KX767090 & MG520911 \\
\hline Ophiosphaerella herpotricha & KY423 & KР690989 & KР690989 & KP690989 & KP691011 \\
\hline
\end{tabular}


Table 1 Continued.

\begin{tabular}{|c|c|c|c|c|c|}
\hline \multirow[t]{2}{*}{ Taxon } & \multirow[t]{2}{*}{ Strain/Specimen No. } & \multicolumn{4}{|c|}{ GenBank accession numbers } \\
\hline & & LSU & ITS & SSU & TEF1- $\alpha$ \\
\hline Ophiosphaerella korrae & ATCC 56289 & KC848509 & KC848509 & KC848509 & KC848515 \\
\hline Ophiosphaerella narmari & ATCC 64688 & KC848510 & KC848510 & KC848510 & KC848516 \\
\hline Paraleptosphaeria dryadis & CBS 643.86 & GU301828 & JF740213 & KC584632 & GU349009 \\
\hline Paraophiobolus arundinis & MFLUCC 17-1789 & MG520965 & MG520945 & MG520984 & MG520912 \\
\hline Paraophiobolus plantaginis & MFLUCC 17-0245 & KY815010 & KY797641 & KY815012 & MG520913 \\
\hline Paraphoma chrysanthemicola & CBS 522.66 & KF251670 & FJ426985 & GQ387521 & --- \\
\hline Paraphoma radicina & CBS 111.79 & KF251676 & KF251172 & EU754092 & --- \\
\hline Parastagonospora italica & MFLUCC 13-0377 & KU058724 & KU058714 & MG520985 & MG520915 \\
\hline Parastagonospora minima & MFLUCC 13-0376 & KU058723 & KU058713 & MG520986 & MG520916 \\
\hline Parastagonospora nodorum & CBS 110109 & KF251681 & KF251177 & --- & --- \\
\hline Parastagonosporella fallopiae & CBS 135981 & MH460545 & MH460543 & --- & --- \\
\hline Parastagonosporella fallopiae & CCTU 1151.1 & MH460546 & MH460544 & --- & --- \\
\hline Phaeopoacea festucae & MFLUCC 17-0056 & KY824767 & KY824766 & KY824769 & --- \\
\hline Phaeosphaeria chiangraina & MFLUCC 13-0231 & KM434280 & KM434270 & KM434289 & KM434298 \\
\hline Phaeosphaeria oryzae & CBS 110110 & KF251689 & KF251186 & GQ387530 & --- \\
\hline Phaeosphaeriopsis glaucopunctata & MFLUCC 13-0265 & KJ522477 & KJ522473 & KJ522481 & MG520918 \\
\hline Phaeosphaeriopsis triseptata & MFLUCC 13-0271 & KJ522479 & KJ522475 & KJ522484 & MG520919 \\
\hline Phaeosphaeriopsis yuccae & MFLUCC 16-0558 & KY554481 & KY554482 & KY554480 & MG520920 \\
\hline Poaceicola arundinis & MFLUCC 15-0702 & KU058726 & KU058716 & MG520988 & MG520921 \\
\hline Poaceicola italica & MFLUCC 13-0267 & KX910094 & KX926421 & KX950409 & MG520924 \\
\hline Populocrescentia ammophilae & MFLUCC 17-0665 & MG829059 & MG828949 & MG829164 & MG829231 \\
\hline Populocrescentia forlicesenensis & MFLUCC 14-0651 & KT306952 & KT306948 & KT306955 & MG520925 \\
\hline Populocrescentia rosae & MFLU 17-0128 & MG829060 & --- & MG829165 & MG829232 \\
\hline Pseudoophiobolus mathieui & MFLUCC 17-1784 & MG520969 & MG520949 & MG520991 & MG520928 \\
\hline Pseudoophiobolus rosae & MFLUCC 17-1786 & MG520972 & MG520952 & MG520993 & MG520930 \\
\hline Pseudoophiobolus urticicola & KUMCC 17-0168 & MG520975 & MG520955 & MG520996 & MG520933 \\
\hline Pseudoophiosphaerella huishuiensis & MLUCC 19-0164 & MK522499 & MK522509 & MK522505 & MK523389 \\
\hline Pseudophaeosphaeria rubi & MFLUCC 14-0259 & KX765299 & KX765298 & KX765300 & MG520934 \\
\hline Sclerostagonospora ericae & CPC 25927 & KX228319 & KX228268 & --- & \\
\hline Sclerostagonospora opuntiae & CBS 118224 & DQ286772 & DQ286768 & --- & --- \\
\hline Scolicosporium minkeviciusii & MFLUCC 12-0089 & KF366382 & --- & KF366383 & --- \\
\hline Septoriella phragmitis & CPC 24118 & KR873279 & KR873251 & --- & --- \\
\hline Setomelanomma holmii & CBS 110217 & GQ387633 & KT389542 & GQ387572 & GU349028 \\
\hline Setophoma terrestris & CBS 335.29 & KF251749 & KF251246 & GQ387526 & --- \\
\hline Stagonospora neglecta & CBS 343.86 & EU754218 & AJ496630 & EU754119 & --- \\
\hline Tintelnotia destructans & CBS 127737 & KY090664 & KY090652 & KY090698 & --- \\
\hline Tintelnotia opuntiae & CBS 376.91 & GU238123 & KY090651 & GU238226 & --- \\
\hline Vagicola arundinis & MFLUCC 15-0027 & KY706129 & KY706139 & KY706134 & MG520936 \\
\hline Vrystaatia aloeicola & CBS 135107 & KF251781 & KF251278 & --- & --- \\
\hline Wojnowicia italica & MFLUCC 13-0447 & KX430001 & KX342923 & KX430002 & KX430003 \\
\hline Wojnowicia rosicola & MFLUCC 15-0128 & MG829091 & MG828979 & MG829191 & --- \\
\hline Wojnowiciella eucalypti & CBS 139904 & KR476774 & KR476741 & --- & --- \\
\hline Xenoseptoria neosaccardoi & CBS 128665 & KF251784 & KF251281 & --- & --- \\
\hline Xenoseptoria neosaccardoi & CBS 120.43 & KF251783 & KF251280 & --- & --- \\
\hline Yunnanensis phagmitis & MFLUCC 17-0315 & MF684863 & MF684862 & MF684867 & MF683624 \\
\hline Yunnanensis phagmitis & MFLUCC 17-1361 & MF684865 & MF684869 & MF684864 & MF683625 \\
\hline
\end{tabular}

Abbreviations: CBS Centraalbureau voor Schimmelcultures, Utrecht, The Netherlands; CPC Collection of Pedro Crous housed at CBS; CCTU Culture Collection of Tabriz University, Tabriz, Iran; GZCC Guizhou Culture Collection, Guizhou, China. MFLUCC Mae Fah Luang University Culture Collection, Chiang Rai, Thailand. 


\section{Results}

\section{Phylogenetic analyses}

A combined LSU-ITS-SSU-TEF1- $\alpha$ matrix was used to infer the phylogenetic affinities of these new taxa among members of Phaeosphaeriaceae. The dataset comprised 106 taxa (including the new strains), with Leptosphaeria doliolum (CBS 505.75) and Paraleptosphaeria dryadis (CBS 643.86) as the outgroup taxa. The dataset comprised 3107 characters including gaps, of which 822 characters belonged to LSU (1-822), 456 characters to ITS (826-1281), 932 characters to SSU (1285-2216) and 888 characters to TEF1- $\alpha$ (2220-3107). The best ML tree revealed by the RAxML analysis is selected to represent the relationships among these taxa and shown in Fig. 1. The trees generated from Bayesian Inference analyses had similar topologies and not presented here.

Phylogeny indicates that all of the newly collected taxa belong to the Phaeosphaeriaceae and the new genus Pseudoophiosphaerella constitutes an independent lineage and closely related to Dlhawksworthia with strong statistical support (MLBP 94\% and BIPP 1.0). Hydeopsis verrucispora sp. nov. is nested in between Dactylidina and Phaeopoacea as a distinct lineage with good support in ML (MLBP 82\%) and BI (BIPP 1.0) analyses. In addition, the new species Hydeomyces pinicola clustered together with the type species of Hydeomyces $(H$. desertipleosporoides) with high support (MLBP 100\%, and BIPP 1.0), while Leptospora hydei sp. nov is assigned within the genus Leptospora, and related to L. thailandica.

\section{Taxonomy}

Pseudoophiosphaerella J.F. Zhang, J.K. Liu \& Z.Y. Liu, gen. nov.

Index Fungorum number: IF 556244; Facesoffungi Number: FoF 05835

Etymology - Refers to the morphological resemblance to Ophiosphaerella.

Type species - Pseudoophiosphaerella huishuiensis.

Saprobic on dead culms of herbaceous plant. Sexual morph: Ascomata scattered, solitary to gregarious, globose to subglobose, dark brown to black, immersed to erumpent, ostiolate. Hamathecium comprising numerous, hyphae-like, trabeculate, branched pseudoparaphyses. Asci cylindrical, 8-spored, bitunicate, fissitunicate, short pedicellate, apically rounded. Ascospores filiform, fasciculate, hyaline and aseptate when young, become pale-yellowish and multi-septate at maturation, lying parallel or spirally coiled, obtuse in one end and towards acute in another end, smooth-walled, guttulate. Asexual morph: Undetermined.

Notes - Our phylogeny indicates that Pseudoophiosphaerella shares a close relationship to Dlhawksworthia with good support. However, it is morphologically different from the latter in having filiform ascospores, while the ascospores in Dlhawksworthia were observed as ellipsoidal or muriform. Although Pseudoophiosphaerella is morphologically similar to Ophiosphaerella (in having long cylindrical asci with septate, filiform ascospores), our multi-gene analyses indicate that they are phylogenetically distant. Hyde et al. (2013), Phookamsak et al. (2014) indicated that many sexual genera within Phaeosphaeriaceae share similar morphological characters, and it is difficult to distinguish these genera based only on morphological examination. Pseudoophiosphaerella is introduced herein as a new genus to accommodate the new species Pseudoophiosphaerella huishuiensis.

Pseudoophiosphaerella huishuiensis J.F. Zhang, J.K. Liu \& Z.Y. Liu sp. nov. Fig. 2 Index Fungorum number: IF 556246; Facesoffungi Number: FoF 05836 Etymology - Refers to the place Huishui county, where the fungus was collected.

Holotype - MFLU 18-2266

Saprobic on dead culms of unidentified herbaceous plant. Sexual morph: Ascomata scattered, solitary to gregarious, globose to subglobose, dark brown to black, immersed to erumpent, ostiolate. Ostiole central, papillate, conical, with a pore-like opening. Peridium $25-34 \mu \mathrm{m}$ thick, 
coriaceous, composed of several layers of thick-walled, brown to dark brown, pseudoparenchymatous cells of textura angularis, become pale brown to hyaline towards inner layers. Hamathecium comprising numerous, 1.5-3 $\mu \mathrm{m}$ wide, hyphae-like, pseudoparaphyses, trabeculate at the base and branched at the apex, anastomosing between and above asci, embedded in a gelatinous matrix. Asci $143-151.5 \times 8-9.5 \mu \mathrm{m}(\bar{x}=148 \times 8.7 \mu \mathrm{m}, \mathrm{n}=25), 8$-spored, bitunicate, fissitunicate, long cylindrical, short pedicellate, apically rounded, with a minute ocular chamber. Ascospores 130.5-151.5 $\times 2.5-3.5 \mu \mathrm{m}(\bar{x}=142.5 \times 3 \mu \mathrm{m}, \mathrm{n}=30)$, filiform, fasciculate, hyaline and aseptate when young, become pale-yellowish and multi-septate at maturation, multiseriate, lying parallel or spirally coiled, obtuse in one end and acute in another end, smooth-walled, guttulate. Asexual morph: Undetermined.

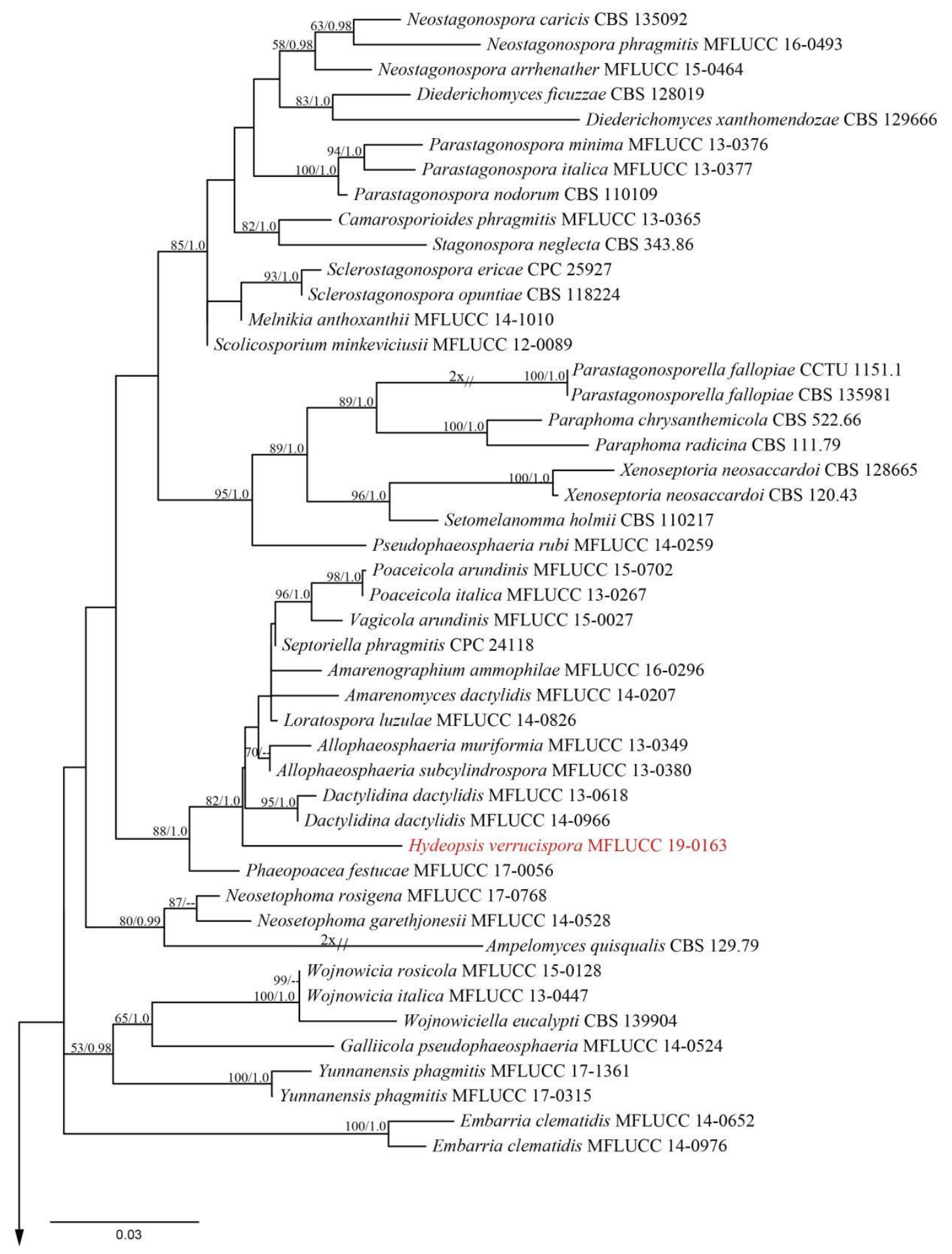




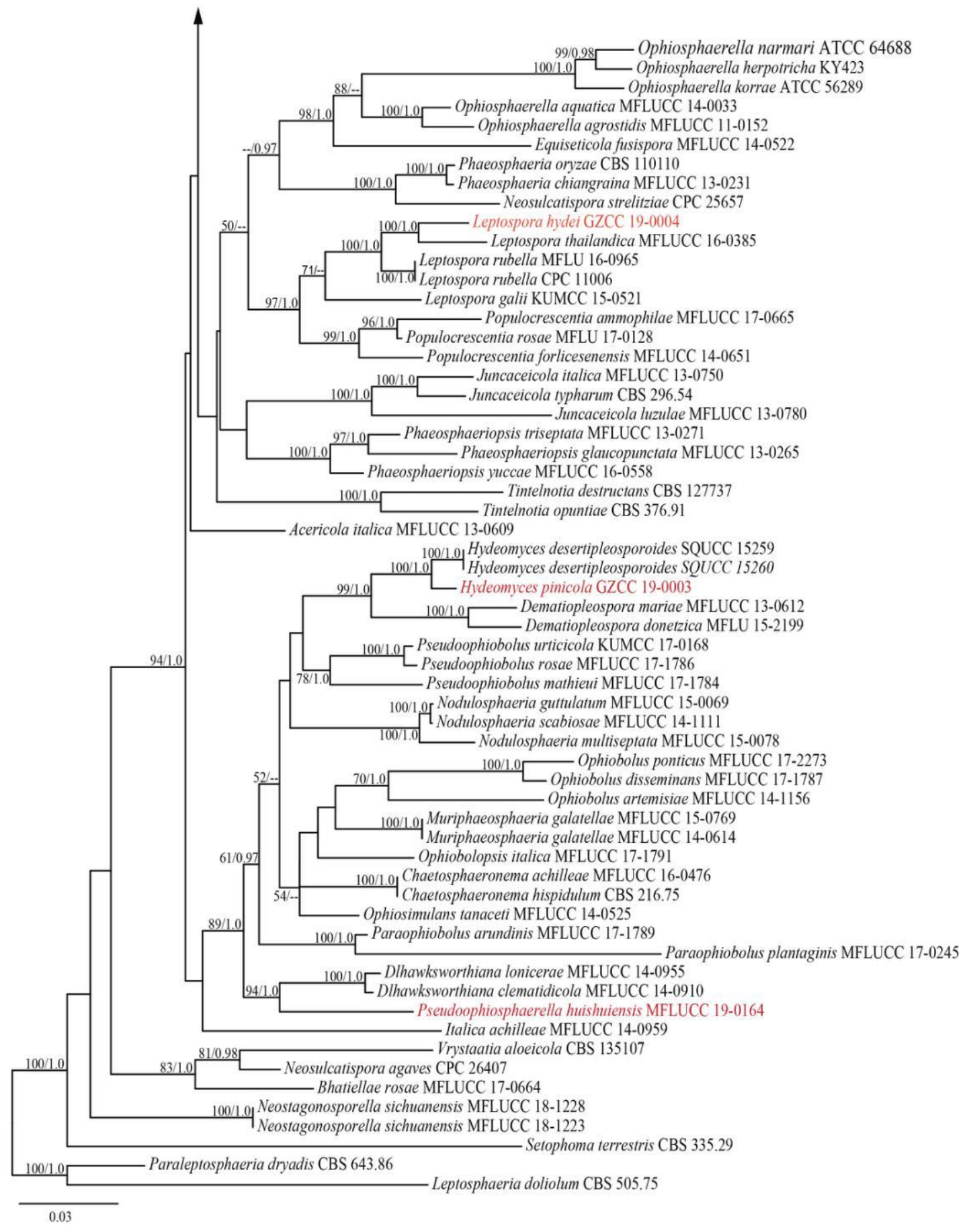

Fig. 1 - Phylogram of the best Maximum Likelihood tree revealed by RAxML analysis of the combined (LSU-ITS-SSU-TEF1- $\alpha$ ) dataset with other members of the Phaeosphaeriaceae. RAxML bootstrap support values (MLBP) $(\geq 50 \%)$ and Bayesian posterior probabilities (BIPP) greater than 0.95 are shown near the nodes. The original isolate numbers are noted after the species name. The tree is rooted to Leptosphaeria doliolum (CBS 505.75) and Paraleptosphaeria dryadis (CBS 643.86), the scale bar shows 0.03 changes.

Culture characteristics - Ascospores germinated within $24 \mathrm{~h}$ in WA. Colonies on PDA reaching $40 \mathrm{~mm}$ diam. after 3 weeks at $25^{\circ} \mathrm{C}$, medium dense, regular in shape, flattened, surface smooth, with edge fimbriate, colony from above cream, from below pale yellowish at the margin, orangish-brown in the centre. 
Material examined - CHINA, Guizhou Province, Huishui county, on dead twigs of unidentified host, 21 July 2017, J.F. Zhang, HS-13 (MFLU 18-2266; GZAAS 18-0008); ex-type living culture (MFLUCC 19-0164, GZCC 19-0002).

Notes - The new taxon Pseudoophiosphaerella huishuiensis is phylogenetically related to Dlhawksworthia species with good support (MLBP 94\% and BIPP 1.00). However, they can be distinguished on the basis of their morphological characteristics as the new taxon is characterized by long cylindrical asci with filiform, fasciculate, multiseriate ascospores, while the members of Dlhawksworthia are characterized by cylindric-clavate asci with ellipsoidal, fusiform, overlapping uniseriate ascospores (Wanasinghe et al. 2018).
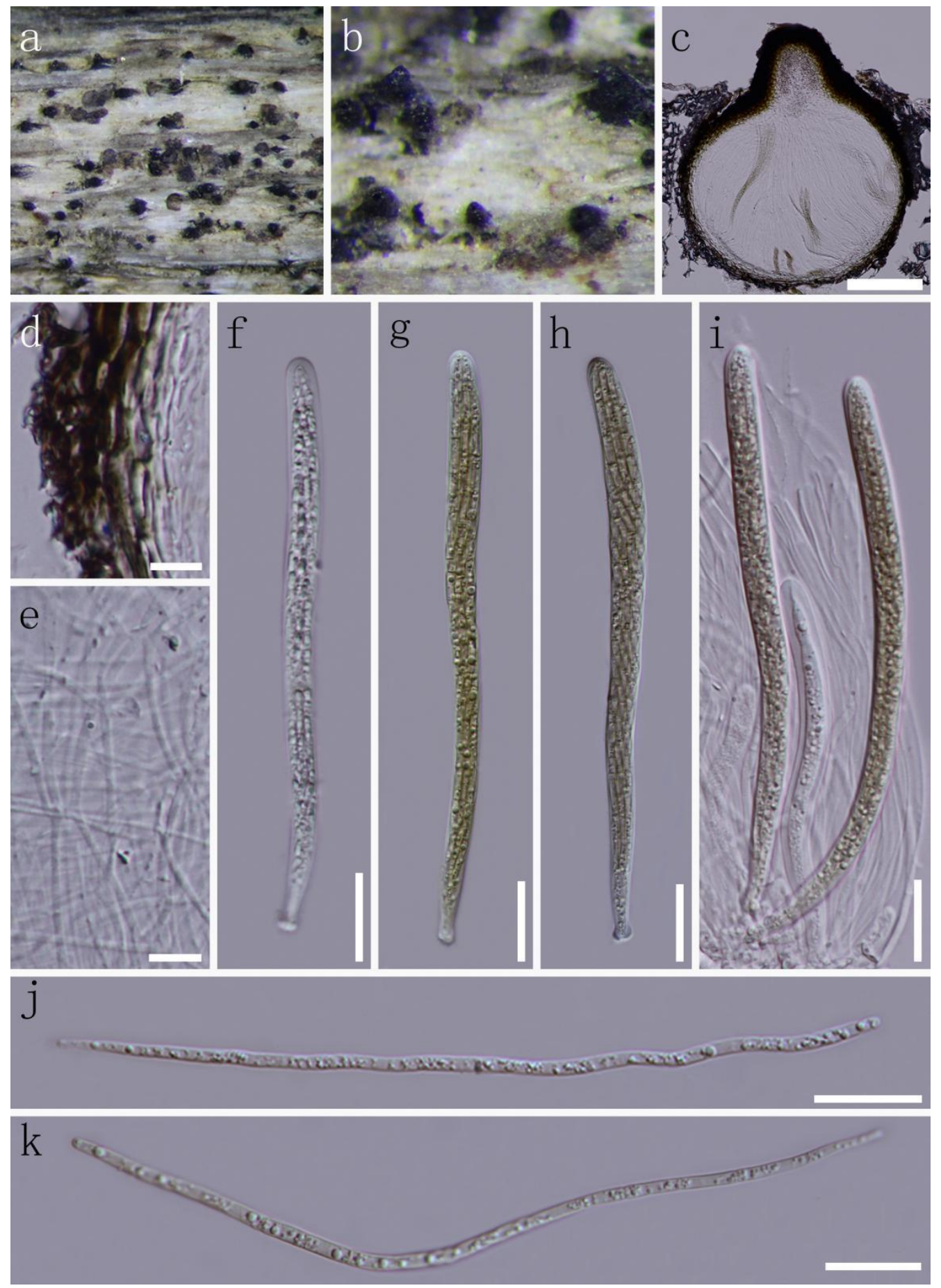

Fig. 2 - Pseudoophiosphaerella huishuiensis (MFLU 18-2266, holotype) a, b Appearance of ascostromata on host surface. c Vertical sections through ascomata. d Section of peridium. e Pseudoparaphyses. f-i Asci. j, k Ascospores. Scale bars: $\mathrm{c}=100 \mu \mathrm{m}, \mathrm{d}, \mathrm{e}=10 \mu \mathrm{m}, \mathrm{f}-\mathrm{k}=20 \mu \mathrm{m}$ 
Hydeopsis J.F. Zhang, J.K. Liu \& Z.Y. Liu, gen. nov.

Index Fungorum number: IF 556247; Facesoffungi Number: FoF 05837

Etymology - Named in honour of Prof. Kevin D. Hyde for his immense contribution to mycology.

Type species - Hydeopsis verrucispora.

Saprobic on dead culms of herbaceous plant. Sexual morph: Ascomata immersed, scattered, solitary, subglobose, dark brown to black, coriaceous, ostiolate. Hamathecium comprising numerous, hypha-like, cellular pseudoparaphyses, anastomosing between and among the asci. Asci clavate, 8-spored, bitunicate, fissitunicate, pedicellate, with a furcate pedicel at the base, rounded to truncate at the apex, with a developed ocular chamber. Ascospores ellipsoidal to fusiform, hyaline to pale pigmented, aseptate when young, and become septate at maturation, constricted at the median septum, surrounded by a mucilaginous sheath. Asexual morph: Undetermined.

Notes - Phylogeny indicates that Hydeopsis can be recognized as member of Phaeosphaeriaceae (Fig. 1), where it is phylogenetically close to Dactylidina and Phaeopoacea. However, it can be differentiated from these genera as it is characterized by ellipsoidal to fusiform, hyaline to pale pigmented, phragmosporous ascospores, while the members of Dactylidina and Phaeopoacea are described as having muriform, dark pigmented ascospores (Liu et al. 2015, Hyde et al. 2017, Wanasinghe et al. 2018b). Although Hydeopsis is morphologically similar to the genera Acericola, Bricckea, Juncaceicola, Loratospora, Phaeosphaeria, Pseudophaeosphaeria, Setomelanomma and Setophoma in having 3-septate, fusiform ascospores (Phookamsak et al. 2014, Ariyawansa et al. 2015, Tennakoon et al. 2016, Hyde et al. 2016, 2017), our multigene phylogeny presented herein indicates that they are phylogenetically distinct genera.

Hydeopsis verrucispora J.F. Zhang, J.K. Liu \& Z.Y. Liu, sp. nov.

Fig. 3

Index Fungorum number: IF 556248; Facesoffungi Number: FoF 05838

Etymology - In reference to the fungus having verrucose ascospores.

Holotype - MFLU 18-2269

Saprobic on dead culms of unidentified herbaceous plant. Sexual morph: Ascomata 191-235 $\mu \mathrm{m}$ high, 186-215 $\mu \mathrm{m}$ wide, immersed, scattered, solitary, subglobose, dark brown to black, coriaceous, ostiolate. Ostiole central, with a flat, pore-like opening. Peridium up to 19-37 $\mu \mathrm{m}$ thick, comprising several layers of dark brown to black, thick-walled cells of textura angularis, outwardly dark pigmented, and become pale brown to hyaline towards inwardly. Hamathecium comprising numerous, 2-3.5 $\mu \mathrm{m}$ wide, hypha-like, cellular pseudoparaphyses, anastomosing between and among asci. Asci (69-) 84.5-93.5 × 11-16.5 $\mu \mathrm{m}(\bar{x}=85 \times 14.5 \mu \mathrm{m}, \mathrm{n}=20), 8$-spored, bitunicate, fissitunicate, clavate, pedicellate, with a furcate stalk at the base, rounded and truncate at the apex, with a developed ocular chamber. Ascospores 18.5-20.5(-23.5) $\times 6-7.5 \mu \mathrm{m}(\bar{x}=20 \times 6.5 \mu \mathrm{m}, \mathrm{n}=$ $25)$, ellipsoidal to fusiform, hyaline to pale brown, verrucose, aseptate when young, and become 3 septate upon maturation, constricted at the median septum, surrounded by a 4.5-7 $\mu \mathrm{m}$ wide, mucilaginous sheath. Asexual morph: Undetermined.

Culture characteristics - Ascospores germinated within $12 \mathrm{~h}$ in WA. Colonies on PDA reaching $66 \mathrm{~mm}$ diam. after 10 days at $25^{\circ} \mathrm{C}$, medium sparse, irregular in shape, flattened, with edge fimbriate, velvety, colony from above semilucent to pale brown, from below pale grayishbrown.

Material examined - CHINA, Guizhou Province, Guiyang City, Huaxi district, dead culms of herbaceous plant, 03 April 2016, J.F. Zhang, SD-2016-5 (MFLU 18-2269; GZAAS 18-0007); extype living culture (MFLUCC 19-0163, GZCC 19-0001).

Notes - The type species of Dactylidina (D. dactylidis) and Phaeopoacea (P. festucae) share close phylogenetic affinities with Hydeopsis verrucispora in both ML (MLBP 82\%) and BI (BIPP 1.0) analyses. Hydeopsis verrucispora also shares some similar morphological characteristics to those species in Dactylidina and Phaeopoacea by having globose or subglobose, glabrous ascomata, cylindrical to clavate asci. However, it can be easily distinguished from members of these two genera as the new taxon is observed to have 3-septate, fusiform ascospores, while the 
members of Dactylidina are characterized by muriform ascospores with 5-6-transverse septate and 1-longitudinal septum (Wanasinghe et al. 2018), and Phaeopoacea species are described with narrowly fusiform ascospores with 5-transverse septate and 1-longitudinal septum in the mid cells (Thambugala et al. 2017).
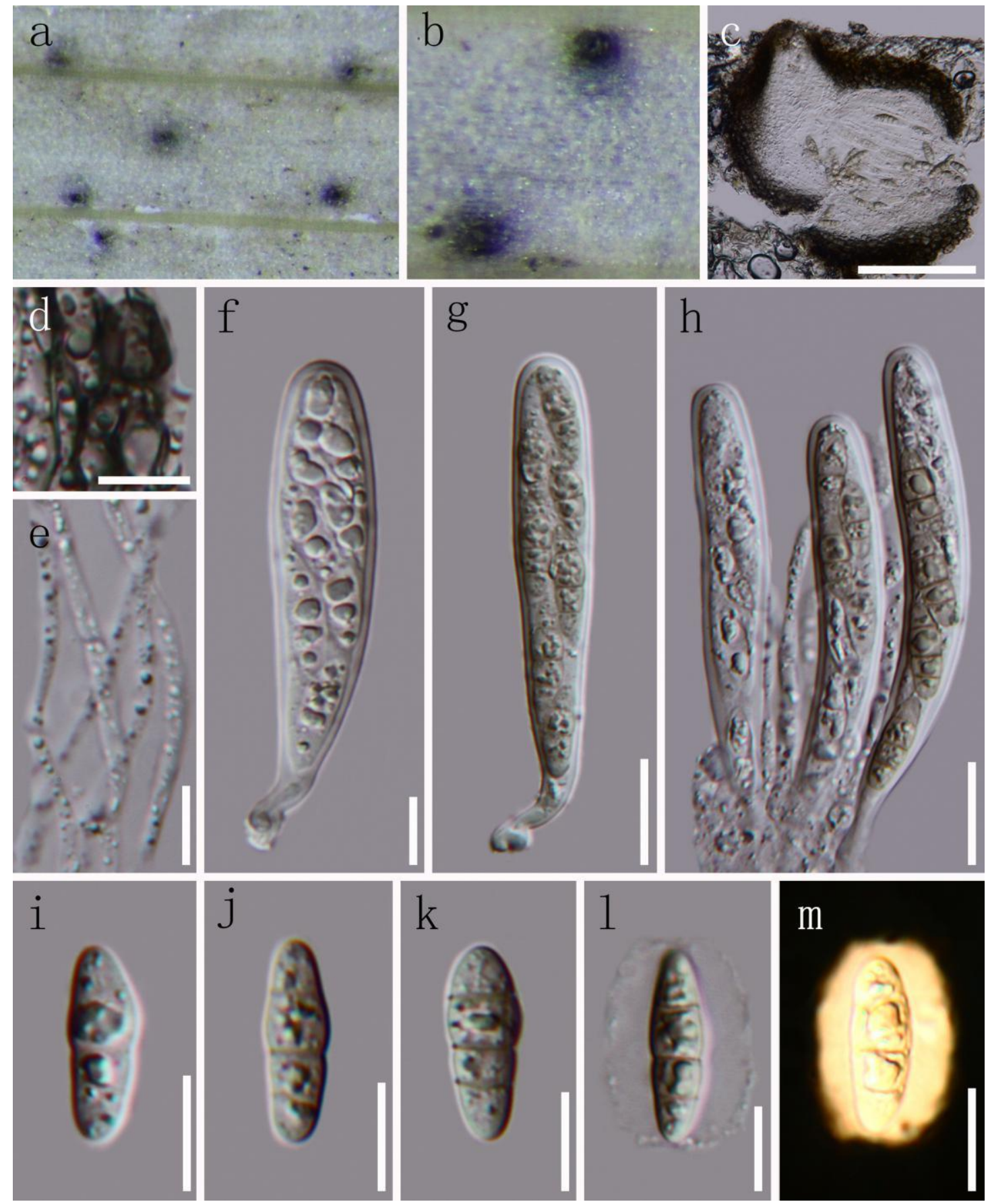

Fig. 3 - Hydeopsis verrucispora (MFLU 18-2269, holotype) a Appearance of ascostromata on host surface. b Ascomata with a central, pore-like opening ostiole. c Vertical sections through ascomata. $\mathrm{d}$ Section of peridium. e Cellular pseudoparaphyses. f-h Asci. i-m Ascospores. Note: the $\mathrm{m}$ is stained with India ink to present the mucilaginous sheath. Scale bars: $c=100 \mu \mathrm{m}, \mathrm{d}-\mathrm{f}, \mathrm{i}-\mathrm{m}=10 \mu \mathrm{m}$, $\mathrm{g}, \mathrm{h}=20 \mu \mathrm{m}$

Hydeomyces Maharachch., H.A. Ariyaw., Wanas. and Al-Sadi., Phytotaxa 391(1): 33 (2019)

Hydeomyces was established by Maharachchikumbura et al. (2019) to accommodate the type species Hydeomyces desertipleosporoides. This genus is morphologically characterized by having 
globose-depressed, brown to black ascomata, cylindrical, fissitunicate asci, ellipsoidal to subfusiform, muriform ascospores, and phoma-like asexual morphs. Until now, only the type species which was isolated from dead barks of Juniperus excels in Oman is known.

Hydeomyces pinicola J.F. Zhang, J.K. Liu \& Z.Y. Liu, sp. nov.

Fig. 4

Index Fungorum number: IF 556249; Facesoffungi Number: FoF 05839

Etymology - Refers to the fungus being isolated from the dead wood of Pinus sp.

Holotype - MFLU 18-2289

Saprobic on dead wood of Pinus sp. Sexual morph: Ascomata 185-417 $\mu \mathrm{m}$ high, 210-341 $\mu \mathrm{m}$ wide, scattered, solitary to gregarious, immersed, semi-immersed to erumpent throughout the host tissue, subglobose, dark brown to black, coriaceous, ostiolate. Ostiole central, with a minute, broadly, flattened papilla, and a pore-like opening. Peridium up to 16-24 $\mu \mathrm{m}$ at the base, $42-59 \mu \mathrm{m}$ at the sides, especially thick near the ostiole, comprising two strata, the outer stratum composed of black, thick-walled cells of textura angularis, fusing with the host tissues, inner stratum composed of several layers of brown to slightly pigmented, thin-walled cells of textura angularis. Hamathecium comprising numerous, 2-3.5 $\mu \mathrm{m}$ wide, hypha-like, septate pseudoparaphyses, branched at the apex, anastomosing between and among asci. Asci 103-111(-119) $\times 9-11.5 \mu \mathrm{m}(\bar{x}$ $=110 \times 10 \mu \mathrm{m}, \mathrm{n}=20$ ), 8 -spored, bitunicate, fissitunicate, cylindrical, short pedicellate with a furcate pedicel, rounded at the apex, with a minute ocular chamber. Ascospores 15.5-19.5 $\times 7-10$ $\mu \mathrm{m}(\bar{x}=17.5 \times 8 \mu \mathrm{m}, \mathrm{n}=35)$, pyriform to subfusiform, muriform, asymmetrical, broader apically and narrower basally, round to truncate at the upper cell, uniseriate, partially overlapping, 3-5transversely septate, with 0-3 vertical septa, initially hyaline, become greenish-brown at maturation, deeply constricted at the central septum, rounded at the ends, smooth-walled. Asexual morph: Undetermined.

Culture characteristics - Ascospores germinated within $24 \mathrm{~h}$ in WA. Colonies on PDA reaching $39 \mathrm{~mm}$ diam. after 15 days at $25^{\circ} \mathrm{C}$, medium sparse, regular in shape, flattened, colony from above yellowish green towards center and colourless at the margin, from below similar with above.

Material examined - CHINA, Guizhou Province, Guiyang City, Huaxi district, Guizhou academy of agricultural sciences, on the dead wood of Pinus sp., 25 Septermber 2016, J.F. Zhang, GZ-06 (MFLU 18-2289, GZAAS 18-0009); ex-type living culture (GZCC 19-0003).

Notes - Phylogenetic analyses place the new species $H$. pinicola in the genus Hydeomyces, where it is close to the type species $H$. desertipleosporoides with high support (MLBP 100\% and BIPP 1.00). Although $H$. pinicola is morphologically similar to $H$. desertipleosporoides in having globose, brown to black ascomata, cylindrical, fissitunicate asci, and subfusiform, muriform ascospores, it can be distinguished from the latter by its larger asci $(103-119 \mu \mathrm{m}$ vs. $70-85 \mu \mathrm{m})$ and ascospores (15.5-19.5 × 7-10 $\mu \mathrm{m}$ vs. 10-15 × 5-6.5 $\mu \mathrm{m})$ (Maharachchikumbura et al. 2019). They are phylogenetically distinct species.

\section{Leptospora Rabenh., Hedwigia 1: 116 (1857)}

Leptospora is typified by L. rubella and characterized by large, flask-shaped ascomata with long cylindrical asci and thin, filiform, multi-septate ascospores, and members of this genus had also been reported to produce a reddish-purple pigmentation to stain the host tissue around the ostiole (Walker 1980, Hyde et al. 2016). So far, there are 16 species included in Index Fungorum (February, 2019), but sequence data are only available in GenBank for a few species.

Leptospora hydei J.F. Zhang, J.K. Liu \& Z.Y. Liu, sp. nov.

Fig. 5

Index Fungorum number: IF 556264; Facesoffungi Number: FoF 05840

Etymology - In honour of Prof. Kevin D. Hyde for his contribution to ascomycete taxonomy. Holotype: MFLU 19-0564 

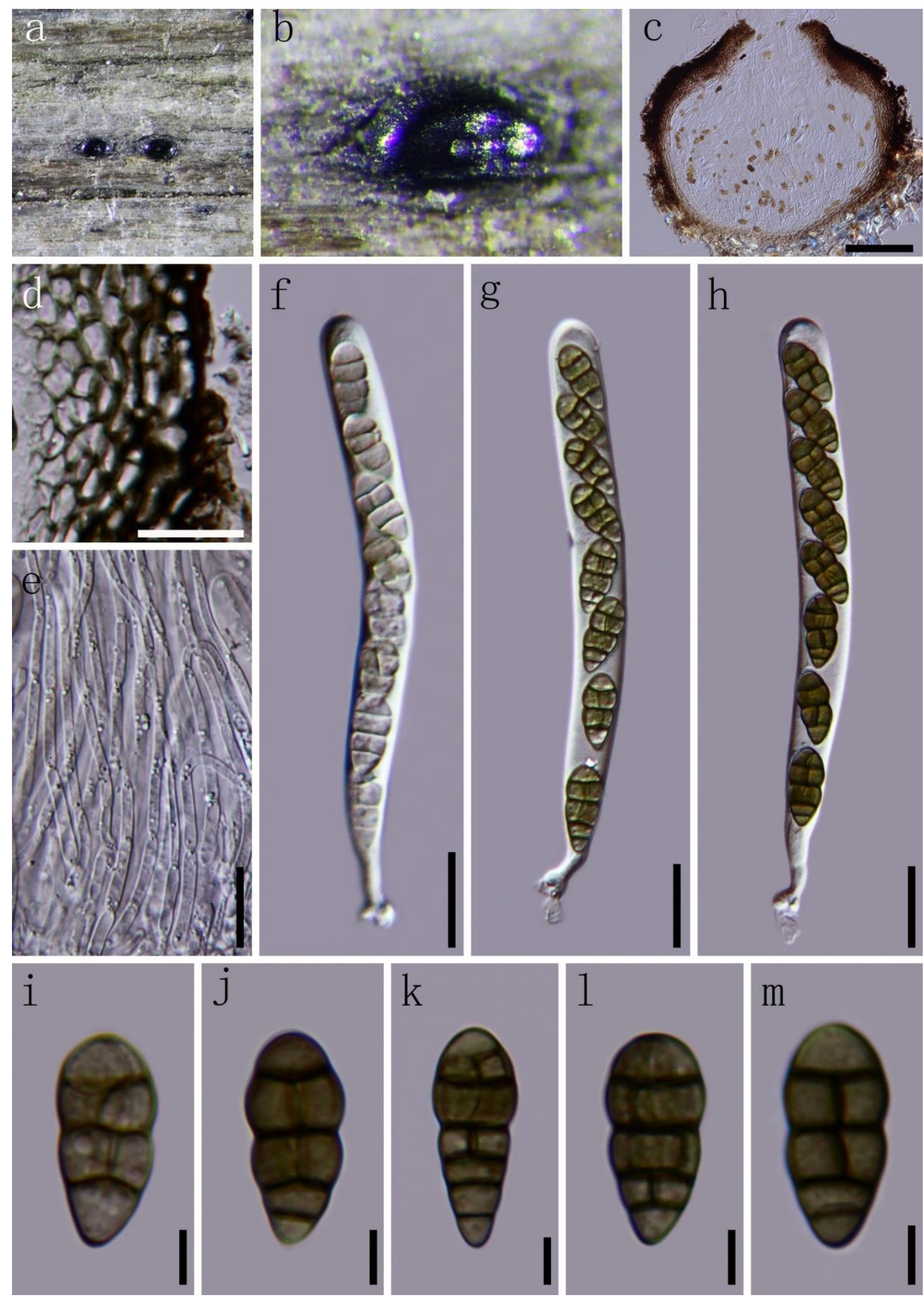

Fig. 4 - Hydeomyces pinicola (MFLU 18-2289, holotype) a Appearance of ascomata on host surface. b Ascomata with a central, pore-like opening ostiole. c Vertical sections through ascoma. d Section of peridium. e Pseudoparaphyses. f-h Asci. i-m Ascospores. Scale bars: $c=100 \mu \mathrm{m}, \mathrm{d}-\mathrm{h}$ $=20 \mu \mathrm{m}, \mathrm{i}-\mathrm{m}=5 \mu \mathrm{m}$

Saprobic on decaying culms of unidentified herbaceous plant. Sexual morph: Ascomata 196$267 \mu \mathrm{m}$ high, 168-187 $\mu \mathrm{m}$ diam, immersed to erumpent through host tissue with papilla, solitary, scattered, depressed globose to subglobose, brown to dark brown, ostiolate. Ostiole central, papillate, cylindrical, truncate at the apex, dark brown to light brown, ostiloar canal filled with 
periphyses, and produces a reddish-purple discoloration in host tissue around ostiole. Peridium up to 11-24 $\mu \mathrm{m}$ wide, coriaceous, composed of several layers of thick-walled, brown to dark brown, pseudoparenchymatous cells, arrange in a textura angularis to prismatica, thin at the base, becoming thick and dark-pigmented towards ostiole. Hamathecium comprising numerous, 1.5-3 $\mu \mathrm{m}$ wide, filamentous, branched, trabeculate pseudoparaphyses anastomosing above and between the asci. Asci 147-165(-180) $\times 13-17(-19.5) \mu \mathrm{m}(\bar{x}=161 \times 15.2 \mu \mathrm{m}, \mathrm{n}=25)$, 8-spored, bitunicate, cylindrical to cylindrical-clavate, with very short swollen pedicel, apically rounded to truncate with a minute ocular chamber. Ascospores $(104-) 124-138(-146) \times 4-4.8 \mu \mathrm{m}(\bar{x}=133.5$ $\times 4.4 \mu \mathrm{m}, \mathrm{n}=30$ ), fasciculate, tri- to multiseriate, scolecosporous, filiform, tapering towards the ends, minute guttules in each cell, hyaline when young, and become pale brown at maturation, normally 11-septate, not constricted at the septa. Asexual morph Undetermined.
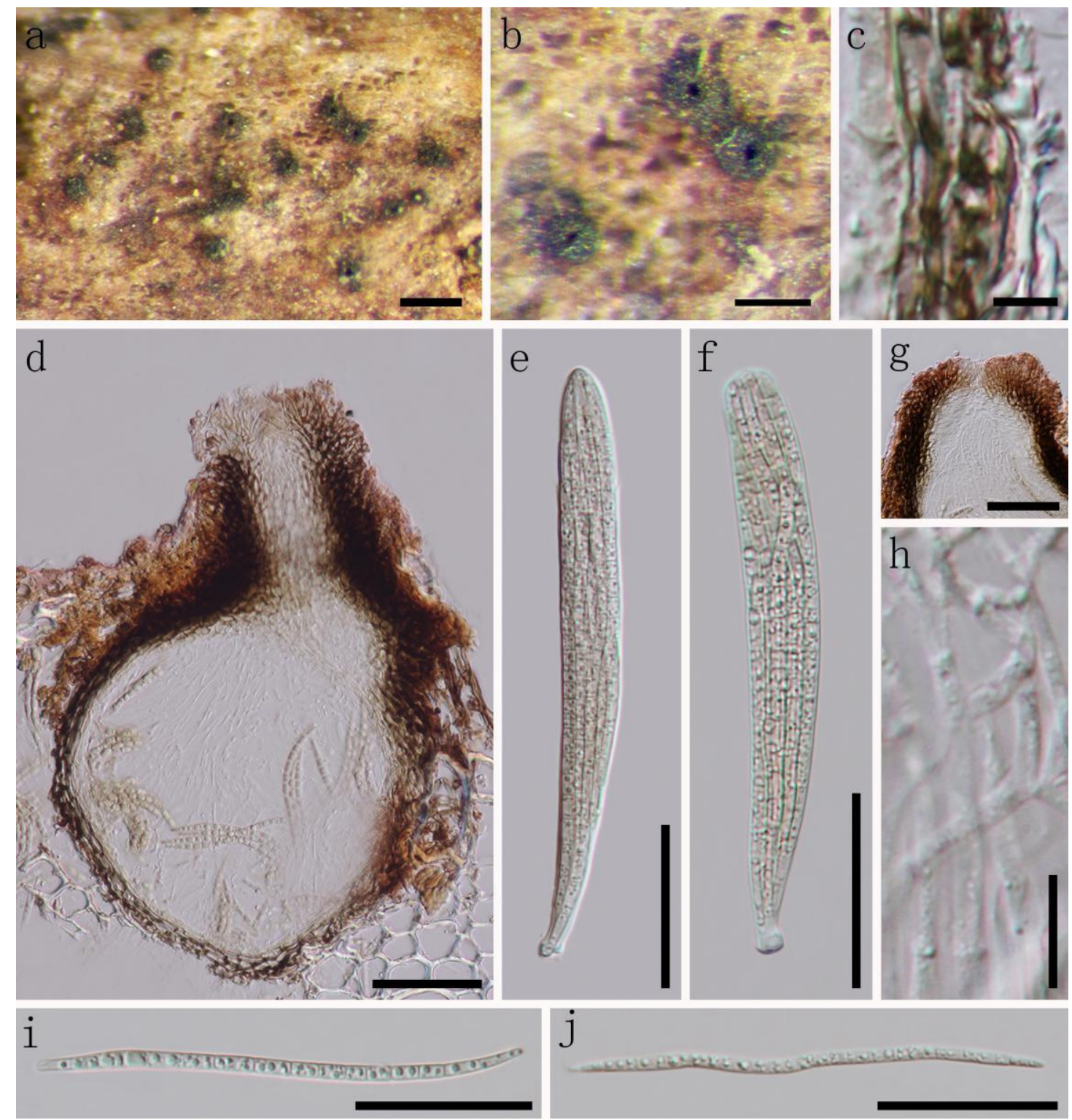

Fig. 5 - Leptospora hydei (MFLU 19-0564, holotype) a Appearance of ascostromata on host surface. $b$ The ostiole on face view. c Peridium. d Vertical section through ascomata. e, f Asci. g Ostiolar canal filled with numerous periphyses. h Pseudoparaphyses. i, $\mathrm{j}$ Ascospores. Scale bars: $\mathrm{a}=200 \mu \mathrm{m}, \mathrm{b}=100 \mu \mathrm{m}, \mathrm{c}=5 \mu \mathrm{m}, \mathrm{d}-\mathrm{g}, \mathrm{i}-\mathrm{j}=50 \mu \mathrm{m}, \mathrm{h}=10 \mu \mathrm{m}$

Culture characteristics - Ascospores germinated within 24h in WA. Colonies on PDA reaching $35 \mathrm{~mm}$ diam. after 4 weeks at $25^{\circ} \mathrm{C}$, medium dense, irregular in shape, raised at center, 
with edge fimbriate, colony from above greyish-green, from below olive in center, and become pale yellowish towards margin.

Material examined - CHINA, Guizhou Province, Guiyang City, Huaxi district, on decaying branch, 20 September 2016, J.F. Zhang, SD-02 (MFLU 19-0564, GZAAS 18-0010); ex-type living culture (GZCC 19-0004).

Notes - Leptospora hydei shares key morphological characters with existing Leptospora species in staining the host tissue with reddish-purple pigmentation around ostiole canal, and filiform, multi-septate ascospores. The phylogenetic result also assigns $L$. hydei to the genus Leptospora, as it clusters together with L. thailandica with strong statistical support (MLBP 100\%, BIPP 1.00). However, it differs from $L$. thailandica in having larger asci (147-180 $\times 13-19.5 \mu \mathrm{m}$ vs. $68-114 \times 7-13 \mu \mathrm{m})$ and ascospores $(104-146 \times 4-4.8 \mu \mathrm{m}$ vs. $63-89 \times 1.8-3.8 \mu \mathrm{m})$, and with less number of septum in ascospores (11-septate vs. 14-22-septate) (Hyde et al. 2016).

\section{Discussion}

Phaeosphaeriaceae taxa are known to be polyphyletic with large overlap in morphological characters among taxa (Phookamsak et al. 2015). There is still confusion between taxa with similar morphological characteristics, and it is difficult to differentiate them based only on observation of phenotypic traits, and therefore DNA sequence data has become more important in their taxonomy (Phookamsak et al. 2017). In the present study, the new genus Pseudoophiosphaerella is quite similar to Ophiosphaerella in having cylindrical asci and filiform ascospores, but it is phylogenetically distant from Ophiosphaerella in both ML and BI analyses, and can be recognized as a distinct genus. Recent molecular studies have indicated that multi-gene analyses are essential to clarify the phylogenetic affinities among the taxa within Phaeosphaeriaceae (de Gruyter et al. 2010, Hyde et al. 2013, Phookamsak et al. 2014, 2017), and we also carried out multi-loci analyses based on LSU, ITS, SSU and TEF1- $\alpha$ sequence data in this study and recovered phylogenies similar to previous studies.

The taxonomic placement of most genera in Phaeosphaeriaceae has been rather well resolved in recent studies (Phookamsak et al. 2014, 2017, Ahmed et al. 2017, Tennakoon et al. 2016, Karunarathna et al. 2017, Maharachchikumbura et al. 2019). There are, however, still, several genera viz. Amarenographium, Amarenomyces, Chaetosphaeronema, Melnikia, Scolicosporium, Septoriella and Lorotospora that are still unresolved lineages and this further complicates intergeneric relationships. There is also insufficient taxa having DNA sequence data for all commonly used genes in phylogeny and this could result in wrong phylogenetic inferences associated with limited taxon sampling (Quaedvlieg et al. 2013, Ariyawansa et al. 2015, AbdElsalam et al. 2016, Hyde et al. 2016, 2017, Wijayawardene et al. 2016, Phookamsak et al. 2017). Therefore, more taxon sampling of these above mentioned genera and the new genera (Hydeopsis and Pseudoophiosphaerella) are needed to gain better understanding of phylogenetic affinities within Phaeosphaeriaceae. In the present study, it was found that, both Hydeopsis and Pseudoophiosphaerella were phylogenetically distinct from other existing genera by high support. Besides, generic delineation between the genera Wonjnowicia and Wonjnowiciella is still unclear despite having phylogenetic data (Wanasinghe et al. 2018). Future taxonomic studies are needed to clarify their taxonomy.

In this study, Hydeomyces pinicola was introduced based on morphological and molecular data. It was isolated from dead wood of Pinus sp. in Guizhou Province of China (subtropical region), while the type species of this genus $H$. desertipleosporoides was reported from dead barks of Juniperus excels in Oman (tropical region) (Maharachchikumbura et al. 2019). It can be inferred herein that Hydeomyces is neither host specific nor geographically restricted. However, there are only two accepted species until now and more samples of this genus should be collected and analyzed to confirm the above statement. In addition, Leptospora hydei is also established in this study. So far, 16 species have been included in this genus (Index Fungorum, February, 2019), and these species inhabit a wide range of hosts and distributed around the world. However, there are no 
records available from China, and this is the first report, and also establishes a new Leptospora species from China.

\section{Acknowledgements}

The Research of Featured Microbial Resources and Diversity Investigation in Southwest Karst area (Project No. 2014FY120100) is gratefully thanked for financial support. Jian-Kui Liu would like to thank the National Natural Science Foundation of China (NSFC 31600032) and Science and Technology Foundation of Guizhou Province(LH [2015]7061). Associate Professor R Jeewon thanks the University of Mauritius. Shaun Pennycook is thanked for providing advice on fungal nomenclature.

\section{References}

Abd-Elsalam KA, Tibpromma S, Wanasinghe DN, Camporesi E, Hyde KD. 2016 - Equiseticola gen. nov. (Phaeosphaeriaceae), from Equisetum sp. in Italy. Phytotaxa 284, 169-180. DOI: 10.11646/phytotaxa.284.3.2

Ahmed SA, Hofmüller W, Seibold M, de-Hoog GS et al. 2017 - Tintelnotia, a new genus in Phaeosphaeriaceae harbouring agents of cornea and nail infections in humans. Mycoses 60, 244-253. DOI: $10.1111 /$ myc. 12588

Ariyawansa HA, Hyde KD, Jayasiri SC, Buyck B et al. 2015 - Fungal diversity notes 111-251: taxonomic and phylogenetic contributions to fungal taxa. Fungal Diversity 75, 27-274. DOI: 10.1007/s13225-015-0346-5

Ariyawansa HA, Hyde KD, Liu JK, Wu SP, Liu ZY. 2016a - Additions to Karst Fungi 1: Botryosphaeria minutispermatia sp. nov., from Guizhou Province, China. Phytotaxa 275, 3544. DOI: $10.11646 /$ phytotaxa.275.1.4

Ariyawansa HA, Hyde KD, Tanaka K, Maharachchikumbura SSN et al. 2016b - Additions to Karst Fungi 3: Prosthemium sinense sp nov., from Guizhou Province, China. Phytotaxa 284, 281291. DOI: $10.11646 /$ phytotaxa.284.4.4

Ariyawansa HA, Hyde KD, Thambugala KM, Maharachchikumbura SSN et al. 2016c - Additions to Karst Fungi 2: Alpestrisphaeria jonesii from Guizhou Province, China. Phytotaxa 277, 255-265. DOI: 10.11646/phytotaxa.277.3.3

Ariyawansa HA, Phillips AJL, Chuang WY, Tsai I. 2018 - Tzeananiaceae, a new pleosporalean family associated with Ophiocordycepsmacroacicularis fruiting bodies in Taiwan. MycoKeys 37, 1-17. DOI: 10.3897/mycokeys.37.27265

Bakhshi M, Arzanlou M, Groenewald JZ, Quaedvlieg W, Crous PW. 2018 - Parastagnosporella fallopiae gen. et sp. nov. (Phaeosphaeriaceae) on Fallopia convolvulus from Iran. Mycological Progress 18, 203-214. DOI: 10.1007/s11557-018-1428-Z

Barr ME. 1979 - A classification of Loculoascomycetes. Mycologia 71, 935-957

Chen YY, Maharachchikumbura SSN, Liu JK, Hyde KD et al. 2017 - Fungi from Asian Karst formations I. Pestalotiopsis photinicola sp. nov., causing leaf spots of Photinia serrulata. Mycosphere 8, 103-110. DOI: 10.5943/mycosphere/8/1/9

Chomnunti P, Hongsanan S, Aguirre-Hudson B, Tian Q et al. 2014 - The sooty moulds. Fungal Diversity 66, 1-36. DOI: 10.1007/s13225-014-0278-5

Dai DQ, Phookamsak R, Wijayawardene NN, Li WJ et al. 2017 - Bambusicolous fungi. Fungal Diversity 82, 1-105. DOI: 10.1007/s13225-016-0367-8

de Gruyter J, Woudenberg JHC, Aveskamp MM, Verkley GJM et al. 2010 - Systematic reappraisal of species in Phoma sextion Paraphoma, Pyrenochaeta and Pleurophoma. Mycologia 102, 1066-1081. DOI: $10.3852 / 09-240$

Ghimire SR, Hyde KD. 2008 - Fungal endophytes. Plant Surface Microbiology pp, 281-292. DOI: 10.1007/978-3-540-74051-3_17

Hall TA. 1999 - BioEdit: a user-friendly biological sequence alignment editor and analysis program for Windows 95/98/NT. In Nucleic Acids Symposium Series 41, 95-98 
Huang SK, Jeewon R, Wanasinghe DN, Manawasinghe IS et al. 2017 - Phylogenetic taxonomy of Dematiopleospora fusiformis sp. nov. (Phaeosphaeriaceae) from Russia. Phytotaxa 316, 239249. DOI: 10.11646/phytotaxa.316.3.3

Hyde KD, Hongsanan S, Jeewon R, Bhat DJ et al. 2016 - Fungal diversity notes 367-490: taxonomic and phylogenetic contributions to fungal taxa. Fungal Diversity 80, 1-270. DOI: 10.1007/s13225-016-0373-x

Hyde KD, Jones EBG, Liu JK, Ariyawansa HA et al. 2013 - Families of Dothideomycetes. Fungal Diversity 63, 1-313. DOI: 10.1007/s13225-013-0263-4

Hyde KD, Norphanphoun C, Abreu VP, Bazzicalupo A et al. 2017 - Fungal diversity notes 603708: taxonomic and phylogenetic notes on genera and species. Fungal Diversity 87: 1-235 DOI: $10.1007 / \mathrm{s} 13225-017-0391-3$

Index Fungorum. 2019 - http://www.indexfungorum.org/Names/Names.asp. Accessed on February 2019

Jaklitsch WM, Voglmayr H. 2016 - Hidden diversity in Thridaria and a new circumscription of the Thyridariaceae. Studies in Mycology 85, 35-64. DOI: 10.1016/j.simyco.2016.09.002

Jayasiri SC, Hyde KD, Ariyawansa HA, Bhat DJ et al. 2015 - The Faces of Fungi database: fungal names linked with morphology, phylogeny and human impacts. Fungal Diversity 74, 3-18 DOI: $10.1007 / \mathrm{s} 13225-015-0351-8$

Jayasiri SC, Hyde KD, Jeewon R, Bhat DJ et al. 2016 - Neooccultibambusa jonesii, a novel taxon within Occultibambusaceae. Mycosphere 7, 1458-1472. DOI: 10.5943/mycosphere/7/9/17

Jeewon R, Hyde KD. 2016 - Establishing species boundaries and new taxa among fungi: recommendations to resolve taxonomic ambiguities. Mycosphere 7, 1669-1677. DOI: 10.5943/mycosphere/7/11/4

Karunarathna A, Papizadeh M, Senanayake IC, Jeewon R et al. 2017 - Novel fungal species of Phaeosphaeriaceae with an asexual/sexual morph connection. Mycosphere 8, 1818-1834 (DOI 10.5943/mycosphere/8/10/8)

Kirk PM, Cannon PF, Minter DW, Stalpers JA. 2008 - Ainsworth and Bisby's dictionary of the fungi, 10th edn. CABI, Wallingford, UK

Kodsueb R, Vijaykrishna D, Aptroot A, Lumyong S et al. 2006 - The family Pleosporaceae: intergeneric relationships and phylogenetic perspectives based on sequence analyses of partial 28S rDNA. Mycologia 98, 571-583. DOI: 10.1080/15572536.2006.11832660

Lawrey JD, Diederich P, Nelsen MP, Freebury C et al. 2012 - Phylogenetic placement of lichenicolous Phoma species in the Phaeosphaeriaceae (Pleosporales, Dothideomycetes). Fungal Diversity 55, 195-213. DOI: 10.1007/s13225-012-0166-9

Liu JK, Chomnunti P, Cai L, Phookamsak R et al. 2010 - Phylogeny and morphology of Neodeightonia palmicola sp. nov. from palms. Sydowia 62, 261-276

Liu JK, Hyde KD, Jeewon R, Phillips AJL et al. 2017 - Ranking higher taxa using divergence times: a case study in Dothideomycetes. Fungal Diversity 84, 75-99. DOI: 10.1007/s13225017-0385-1

Liu JK, Jones EBG, Ariyawansa HA, Bhat DJ et al. 2015 - Fungal diversity notes 1-110: taxonomic and phylogenetic contributions to fungal species. Fungal Diversity 72, 1-197. DOI 10.1007/s13225-015-0324-y

Nylander J. 2008 - MrModeltest2 version 2.3 (program for selecting DNA substitution models using PAUP*). Evolutionary Biology Centre, Uppsala, Sweden

Page RDM. 1996 - TREEVIEW, tree drawing software for Apple Macintosh and Microsoft Windows. Division of Environmental and Evolutionary Biology, Instituteo Biomedical and Life Sciences, University of Glasgow. Glasgow, Scotland, UK

Phookamsak R, Liu JK, McKenzie EHC, Manamgoda DS et al. 2014 - Revision of Phaeosphaeriaceae. Fungal Diversity 68, 159-238. DOI: 10.1007/s13225-014-0308-3

Phookamsak R, Norphanphoun C, Tanak K, Dai DQ et al. 2015 - Towards a natural classification of Astrosphaeriella-like species; introducing Astrosphaeriellaceae and 
Pseudoastrosphaeriellaceae fam. nov. and Astrosphaeriellopsis, gen. nov. Fungal Diversity 74, 143-197. DOI: 10.1007/s13225-015-0352-7

Phookamsak R, Wanasinghe DN, Hongsanan S, Phukhamsakda C et al. 2017 - Towards a natural classification of Ophiobolus and ophiobolus-like taxa; introducing three novel general Ophiobolopsis, Paraophiobolus and Pseudoophiobolus in Phaeosphaeriaceae (Pleosporales). Fungal Diversity 87, 299-339. DOI: 10.1007/s13225-017-0393-1

Promputtha I, Hyde KD, McKenzie EHC, Peberdy JF, Lumyong S. 2010 - Can leaf degrading enzymes provide evidence that endophytic fungi becoming saprobes? Fungal Diversity 41, 89-99. DOI: 10.1007/s13225-010-0024-6

Promputtha I, Lumyong S, Dhanasekaran V, McKenzie EHC et al. 2007 - A phylogenetic evolution of whether endophytes become saprotrophs at host senescence. Microbial Ecology 53, 579-590. DOI: 10.1007/s00248-006-9117-x

Quaedvlieg W, Verkley GJM, Shin H-D, Barretto RW et al. 2013 - Sizing up Septoria. Studies in Mycology 75, 307-390. DOI: 10.3114/sim0017

Rannala B, Yang Z. 1996 - Probability distribution of molecular evolutionary trees: a new method of phylogenetic inference. Journal of Molecular Evolution 43, 304-311. DOI: 10.1007/BF02338839

Rehner S. 2001 - Primers for elongation factor 1- $\alpha$ (EF1- $\alpha)$, available at http://ocid.NACSE.ORG/research/deephyphae/EF1primer.pdf

Ronquist F, Teslenko M, van der Mark P, Ayres DL et al. 2012 - MrBayes 3.2: efficient Bayesian phylogenetic inference and model choice across a large model space. Systematic Biology 61, 539-542. DOI 10.1093/sysbio/sys029

Senanayake IC, Jeewon R, Camporesi E, Hyde KD et al. 2018 - Sulcispora supratumida sp. nov. (Phaeosphaeriaceae, Pleosporales) on Anthoxanthum odoratum from Italy. MycoKeys 38, 35-46. DOI: $10.3897 /$ mycokeys.38.27729

Silvestro D, Michalak I. 2012 - raxmlGUI: a graphical front-end for RAxML. Organisms Diversity and Evolution 12, 335-337. DOI: 10.1007/s13127-011-0056-0

Szilagyi-Zecchin VJ, Adamoski D, Gomes RR, Hungria M et al. 2016 - Composition of endophytic fungi community associated with leaves pf maize cultivated in south Brazilian field. Acta Microbiologica et Immunologica Hungarica 63, 449-466

Tanaka K, Hirayama K, Yonezawa H, Sato G et al. 2015 - Revision of the Massarineae (Pleosporales, Dothideomycetes). Studies in Mycology 82, 75-136. DOI: 10.1016/j.simyco.2015.10.002

Tennakoon DS, Hyde KD, Phookamsak R, Wanasinghe DN et al. 2016 - Taxonomy and phylogeny of Juncaceicola gen. nov. (Phaeosphaeriaceae, Pleosporinae, Pleosporales). Cryptogamie Mycologie 37, 135-156. DOI: 10.7872/crym/v37.iss2.2016.135

Thambugala KM, Wanasinghe DN, Phillips AJL, Camporesi E et al. 2017 - Mycosphere notes 150: Grass (Poaceae) inhabiting Dothideomycetes. Mycosphere 8, 697-796. DOI: 10.5943/mycosphere/8/4/13

Tibpromma S, Liu JK, Promputtha I, Camporesi E et al. 2016 - Ophiosimulans tanaceti gen. et sp. nov. (Phaeosphaeriaceae) on Tanacetum sp. (Asteraceae) from Italy. Mycolgical Progress 15, 1-11. DOI: $10.1007 / \mathrm{s} 11557-016-1187-7$

Vilgalys R, Hester M. 1990 - Rapid genetic identification and mapping of enzymatically amplified ribosomal DNA from several Cryptococcus species. Journal of Bacteriology 172, 4238-4246. DOI: $10.1128 / \mathrm{jb} .172 .8 .4238-4246.1990$

Walker JM. 1980 - Gaeumannomyces, Linocarpon, Ophiobolus and several other genera of scolecospored ascomycetes and Phialophora conidial states, with a note on hyphopodia. Mycotaxon 11, 11-29

Wanasinghe DN, Jeewon R, Jones EBG, Tibpromma S, Hyde KD. 2017 - Saprobic Dothideomycetes in Thailand: Muritestudina gen. et sp. nov. (Testudinaceae) a new terrestrial pleosporalean ascomycete, with hyaline and muriform ascospores. Studies in Fungi 2, 219-234. DOI: 10.5943/sif/2/1/26 
Wanasinghe DN, Phukhamsakda C, Hyde KD, Jeewon R et al. 2018 - Fungal diversity notes 709-839: taxonomic and phylogenetic contributions to fungal taxa with an emphasis on fungi on Rosaceae. Fungal Diversity 89, 1-236. DOI: 10.1007/s13225-018-0395-7

Wang HK, Aproot A, Crous PW, Hyde KD, Jeewon R. 2007 - The polyphyletic nature of Pleosporales: An example from Massariosphaeria based on ribosomal DNA and RBP2 gene phylogenies. Mycological Research 111, 1268-1276. DOI: 10.1016/j.mycres.2007.08.014

White T, Bruns T, Lee S, Taylor J. 1990 - Amplification and direct sequencing of fungal ribosomal RNA genes for phylogenetics. In: Innis M, Gelfand D, Shinsky J, White T. (Eds.) PCR protocols: a guide to methods and applications. Academic Press, New York, pp, 315-322

Wijayawardene NN, Hyde KD, Wanasinghe DN, Papozadeh M et al. 2016 - Taxonomy and phylogeny of dematiaceous coelomycetes. Fungal diversity 77, 1-316. DOI: 10.1007/s13225016-0360-2

Wijayawardene NN, Hyde KD, Lumbsch HT, Liu JK et al. 2018 - Outline of Ascomycota: 2017. Fungal Diversity 88, 167-263. DOI: 10.1007/s13225-018-0394-8

Wong MKM, Hyde KD. 2001 - Diversity of fungi on six species of Gramineae and one species of Crperaceae in Hong Kong. Mycological Research 105, 1485-1491. DOI: 10.1017/S0953756201004695

Yang CL, Xu XL, Wanasinghe DN, Jeewon R et al. 2019 - Neostagonosporella sichuanensis gen. et sp. nov. (Phaeosphaeriaceae, Pleosporales) on Phyllostachys heteroclada (Poaceae) from Sichuan Province, China. Mycokeys 46, 119-150. DOI: 10.3897/mycokeys.46.32458

Yang JW, Yeh YH, Kirschner R. 2016 - A new endophytic species of Neostagonospora (Pleosporales) from the coastal grass Spinifex littoreus in Taiwan. Botany 94, 593-598

Zhang JF, Liu JK, Hyde KD, Chen YY et al. 2017a - Two new species of Dyfrolomyces (Dyfrolomycetaceae, Dothideomycetes) from karst landforms. Phytotaxa 313, 267-277. DOI: 10.11646/phytotaxa.313.3.4

Zhang JF, Liu JK, Hyde KD, Yang W, Liu ZY. 2017b - Fungi from Asian Karst formations II. Two new species of Occultibambusa (Occultibambusaceae, Dothideomycetes) from karst landforms of China. Mycosphere 8, 550-559. DOI: 10.5943/mycosphere/8/4/4

Zhang JF, Liu JK, Ran HY, Khongphinitbunjong K, Liu ZY. 2018 - A new species and new record of Lophiotrema (Lophiotremataceae, Dothideomycetes) from karst landforms in southwest China. Phytotaxa 379, 169-179. DOI 10.11646/phytotaxa.379.2.5

Zhang Y, Crous PW, Schoch CL, Hyde KD. 2012 - Pleosporales. Fungal Diversity 53, 1-221. DOI: $10.1007 / \mathrm{s} 13225-011-0117-\mathrm{x}$

Zhang Y, Jeewon R, Fournier J, Hyde KD. 2008 - Multi-gene phylogeny and morphotaxonomy of Amniculicola lignicola: novel freshwater fungus from France and its relationships to the Pleosporales. Mycological Research 112, 1186-1194

Zhaxybayeva O, Gogarten JP. 2002 - Bootstrap, Bayesian probability and maximum likelihood mapping: exploring new tools for comparative genome analyses. BMC Genomics 3, 4. DOI: $10.1186 / 1471-2164-3-4$ 